\title{
OBSERVATIONS ON THE GENUS CONTARINIA
}

By E. P. Felt, Albany, N. Y.

This genus is of economic importance, despite the fact that the insect Americans have hitherto known as Diplosis or Contarinia tritici Kirby can not be referred thereto. In passing, we wish to state that there is some question as to the identity of Diplosis tritici, and the writer would appreciate most thoroughly any assistance other entomologists could give in the way of securing additional material this season. Similarly, Diplosis violicola Coq., though a species of much importance to violet growers, can not be retained in this genus.

One of the best known members of the genus is $C$. pyrivora Riley, an insect which was brought into this country about 1877 and which has caused a large amount of injury to pear growers, particularly in Connecticut, New York and New Jersey. This importation is a very well marked form, differing so widely from American species that one antennal segment of the male is sufficient for its recognition. Careful comparisons between American-bred insects and others received from Europe have established the identity of the two beyond question. There is but one generation annually, the larvæ wintering in the ground in oval, silken cocoons, the adults appearing about the time pears are in bloom. According to Schmidberger, the eggs are deposited on the anthers of the closed blossom to the number of 10 or 12 , and in warm weather hatch in about four days. The young larvæ develop rapidly, penetrating to the core and feeding upon the interior. The affected fruit becomes characteristically deformed. June rains cause it to crack and decay rapidly, thus allowing the larvæ to escape and enter the soil, imagoes developing the following spring.

The recent studies of Mr. C. R. Ball have shown that Contarinia (Diplosis) sorghicola Coq. may be responsible for the failure of sorghum to produce a full crop of seed in our southern states. This trouble, Mr. Ball states, has been variously attributed to fungi, insects and unfavorable meteorlogical conditions, such as excessive precipitation, high humidity, severe drought and hot winds. Mr. Ball's experiments showed that heads protected from the midge were uniformly fertile where the growth was normal, while those exposed during the first half of anthesis and then protected were sterile in the upper portion and well seeded below. Mr. Ball succeeded in rearing from 500 to 1,160 midges from each of several infested heads. He also reared a parasite from this insect referable to the genus Aprostocetus. 
A widely distributed form in the eastern states, Contarinia liriodendri O. S., is responsible for a beautiful and characteristic blister gall upon the leaves of tulip, Liriodendron. The gall is a nearly circular, somewhat convex blister mine about $5 \mathrm{~mm}$. in diameter. The dark brown center is surrounded by a light brown, irregular area which is slightly darker on its upper margin, the coloration of both surfaces being approximately the same. The partly developed gall has a dark brown, slightly elevated, circular central portion surrounded by pale green, which in turn is encircled by pale yellow, shading into pale green and that again into the color of the normal leaf tissue. This species was first reared by Mr. J. G. Jack and brief descriptions published of the gall, larva and adult in 1889. Mr. Jack's observations show that in the vicinity of Boston there are three or more generations annually, the broods so overlapping that some larvæ may be found at almost any time. He states that the first eggs are probably laid in the spring on the unfolding leaves, while the last larvæ attain full growth about the end of September. The transformations occur in the ground, the late appearing larvæ probably remaining unchanged till spring. This gall insect is so abundant in many places as to seriously affect the foliage of its food plant.

Contarinia ananassi Riley, originally described as Cecidomyia cupressi-ananassi, is another member of this genus, chiefly interesting because of the characteristic gall it produces on cypress twigs, Taxodium distichum. This gall is a pale brown, sparsely pruinose, ovate swelling on the twig some $1.25 \mathrm{~cm}$. long and bearing numerous transverse, knife-edge-like elevations. This deformity is evidently an enlargement of the growing stem, the transverse elevations corresponding to the leaf scars. The normal fibers of the twig are easily detected in the central portion of the gall, which later may contain from three to eight larvæ in a spongy, golden brown mass. Adults were bred in May and there is probably but one generation annually.

The European Contarinia rumicis Low. was bred last July from reddish or brown seeds of curled dock, Rumex crispus, taken at Newport, N. Y. Professor Trail states, in the Scottish Naturalist, that this species also occurs in the swollen buds of sheep-sorrel, Rumex acetosella. This weed is abundant in our section of the country and it is somewhat surprising, if it has this habit in America, that we have not taken this species at large in our extensive collecting during the last two or three years.

Contarinia gossypii Felt is a species which has recently been brought to attention because of its injuring cotton in the British West Indies. No information is at hand as to the precise character of the damage. 
Contarinia setigera Lintn. was bred a number of years ago by the late Doctor Lintner, from shoots of musk melon, the young leaves of which had been transformed into a small, irregular, subovate, downy gall, presumably made by this insect.

Contarinia negundifolia Felt MS. was reared from the leaves of box elder, Negundo aceroides, collected in Virginia by Mr. Theodore Pergande May 12, 1884. Mr. Pergande states that the larvæ deserted the galls May 15 and entered the ground, remaining there until the following spring. It is possible that this last named species may prove to be identical with Cecidomyia negundinis Gill., a species which has been recorded by Professor Gillette as being quite injurious to box elder trees on the college campus at Ames, Iowa. It has been impossible up to the present to obtain for comparison specimens of the last named form.

There are several other American species referable to this genus, some with unknown habits. Contarinia perfoliata Felt MS. was bred in August, 1907, from the florets of thoroughwort, Eupatorium perfoliatum. Another undescribed species, Contarinia quercifolia Felt MS., has been reared from oak, presumably in connection with a Cynipid gall, though we have no exact record in respect to the same. Contarinia agrimoniae Felt was reared in September, 1907, from yellowish larvæ in the florets of Agrimonia eupatoria taken at Bath, N. Y. Contarinia virginianiae Felt, originally described as Cecidomyia, was bred June 1 by Dr. James Fletcher, from the deformed fruit of Prunus virginiana. Another undescribed species, Contarinia clematidis Felt MS., has been reared from an irregular subglobular gall taken on clematis at Newport, N. Y., July 24, 1907.

The above shows that members of the genus Contarinia, as at present restricted, display a marked preference for florets, fruits or buds, C. liriodendri and C. ananassi being marked exceptions thereto, though the latter is more apparent than real, since the gall appears to be developed from the rapidly growing, more tender portion of the twig, which is consequently allied to floral and bud tissues noted above. There seems to be no rule as to the number of generations produced annually by members of this genus. A few forms at least breed throughout the season, while others, apparently limited by conditions presented by the food plant, have but one generation annually. This limitation of the number of generations by conditions of the food plant agrees with observations made upon better known species of the group, such as Mayetiola destructor Say. 


\section{$2 \mathrm{BHL}$ Biodiversity Heritage Library}

Felt, Ephraim Porter. 1908. "Observations on the genus Contarinia." Journal of economic entomology 1(3), 225-227. https://doi.org/10.1093/jee/1.3.225.

View This Item Online: https://www.biodiversitylibrary.org/item/37189

DOI: https://doi.org/10.1093/jee/1.3.225

Permalink: https://www.biodiversitylibrary.org/partpdf/325870

\section{Holding Institution}

New York Botanical Garden, LuEsther T. Mertz Library

\section{Sponsored by}

The LuEsther T Mertz Library, the New York Botanical Garden

\section{Copyright \& Reuse}

Copyright Status: NOT_IN_COPYRIGHT

This document was created from content at the Biodiversity Heritage Library, the world's largest open access digital library for biodiversity literature and archives. Visit BHL at https://www.biodiversitylibrary.org. 